\title{
Conversion Process of Molten Fly Ash into Functional Materials using Waste Plastics
}

\author{
Takaaki WAJIMA* \\ ※Department of Urban Environment Systems, Graduate School of Engineering, Chiba University, Chiba 263-8522, Japan \\ E-mail :wajima@tu.chiba-u.ac.jp
}

\begin{abstract}
A new two-step process, chlorination reduction of molten fly ash with waste plastics (PVC) to separate harmful substances, such as $\mathrm{Na}, \mathrm{K}, \mathrm{Cl}, \mathrm{Zn}$ and $\mathrm{Pb}$, from the ash, and transformation from the ash into functional materials by hydrothermal treatment with sodium hydroxide, was attempted. The ash was mixed with PVC $(1: 1)$, and then the mixture was heated at $1000^{\circ} \mathrm{C}$ in nitrogen gas. After heating, the residue was heated again at $1000^{\circ} \mathrm{C}$ in air to obtain the treated ash. Although raw ash contains harmful substances such as $\mathrm{Na}, \mathrm{K}, \mathrm{Cl}, \mathrm{Zn}$ and $\mathrm{Pb}$, treated ash has lower contents of these substances than raw ash. Mineral phases in treated ash are mainly gehlenite, due to the disappearance of sodium chloride and potassium chloride in raw ash by two-step treatment with PVC. While a large amount of harmful ions, $\left(\mathrm{Na}^{+}, \mathrm{K}^{+}, \mathrm{Cl}^{-}, \mathrm{Zn}^{2+}\right.$ and $\left.\mathrm{Pb}^{2+}\right)$ were eluted, the elution of $\mathrm{Na}^{+}$and $\mathrm{K}^{+}$from treated ash was not observed, and those of $\mathrm{Cl}^{-}, \mathrm{Zn}^{2+}$ and $\mathrm{Pb}^{2+}$ decreased. Raw ash or treated ash was treated with $2 \mathrm{M} \mathrm{NaOH}$ solution at $180^{\circ} \mathrm{C}$ for $20 \mathrm{~h}$ to obtain functional materials. From both ashes, tobermorite $11 \AA$ and hydroxyapatite can be synthesized.
\end{abstract}

Key Words : Waste plastics, Molten fly ash, Heating, Alkali treatment, Tobermorite $11 \AA$, Hydroxyapatite

\section{INTRODUCTION}

Waste incineration ash produced by burning waste generated in our daily lives is becoming a severe social problem. Recently, municipal solid waste (MSW) is treated using gasifying and melting furnace, and a large part of the molten fly ash, which is handled as a specially-controlled waste in the same manner as incineration fly ash (fly ash from stoker-type incinerators), is generated. In Japan, more than 0.1 million tons of MSW molten fly ash is estimated to be discharged every year as a result of an increasing number of MSW melting plants [1]. This molten fly ash generally contains harmful substances, especially heavy metals such as lead, zinc, and copper, and is disposed of by landfill burial after stabilization treatment by methods designated by the national government, such as chelate treatment or cement fixation. Furthermore, a shortage of landfill disposal sites has become a major social problem. The establishment of a technology which separates harmful substances such as lead, zinc, etc. in fly ash as completely as possible, and enables recycling of the residue has been desired.

In addition, the content of heavy metals is usually higher than that of their respective metal ores [2]. Given this, it seems to be of great importance to develop effective separation technologies for removal and recovery of heavy metals from molten fly ash. Recently, wet processes such as acid extraction [3-5], electrodialytic separation [6], and solvent extraction [7] have been proposed for metal recovery from molten fly ash, and it was reported that these methods can be used to recover heavy metals in a highly concentrated form. Separation techniques based on dry processes such as reduced volatilization and chloride-induced volatilization has been recently proposed. In the case of reduced volatilization, separation of heavy metals from molten fly ash has been studied [1]. As a result, zinc and lead recovery levels from molten fly ash as high as $90 \%$ were achieved at $1573 \mathrm{~K}$, and in addition, $99 \%$ of the dioxin content was decomposed. Furthermore, it was reported that $95 \%$ of lead and zinc were volatilized from molten fly ash in the presence of reducing agents, carbon and polyvinyl chloride (PVC) [8-12]. Moreover, to reduce energy consumption, volatilization and separation of heavy metals by chloride-induced volatilization has been studied by several researchers using $\mathrm{CaCl}_{2}$, etc. [13-16]. In general, the inorganic chlorides, $\mathrm{NaCl}, \mathrm{KCl}$, and $\mathrm{CaCl}_{2}$ are present in molten fly ash, and these inorganic chlorides are supposed to function as chlorinating agents, and the volatilization of heavy metals was found to increase with addition of inorganic chlorides and the increase became higher in order $\mathrm{CaCl}_{2}>\mathrm{NaCl}>\mathrm{KCl}$ [17].

This research was based on the idea that target metals of the ash can be recovered as chlorides by volatilization using waste polyvinyl chloride (PVC) as the source of chlorine and reductant. PVC is the second most important polymer worldwide and a largescale chemical product. Thanks to its excellent cost/performance ratio and outstanding chemical and environmental resistance, it is today mainly used for long-life applications. However, plastic wastes have an immense impact on the environment because plastics are non-biodegradability and take a long time to break down when they are landfill [18]. Therefore, new ways to use waste plastics are desired. PVC is composed of about $57 \%$ chlorine and about $43 \%$ hydrocarbon. It begins emitting hydrogen chloride gas by pyrolysis under $300^{\circ} \mathrm{C}$ and remains hydrocarbon. Hydrogen chloride gas may pose a problem during the incineration of waste, but it can be used as a provider of chlorine. Moreover, the residual 
hydrocarbon of PVC can be used as a reductant.

After the removal of harmful substances, the residual ash, which is desired for recycling, are produced. Though use of waste ash as a raw material for cement synthesis has been attempted, the technology faces problems such as cost and quality. One of the recycling ways of the ash is to convert the ash into useful material. Many researchers have reported the conversion of incineration fly ashes, noticing that the main components of the ash were $\mathrm{SiO}_{2}$, $\mathrm{Al}_{2} \mathrm{O}_{3}$ and $\mathrm{CaO}$, into materials such as zeolite, tobermorite and hydrogrossular, to be used for environmental purification [1925]. Therefore, it is considered that material conversion from the ash without harmful substances into functional materials for environmental application is favorable.

In this study, a novel two-step treatment process using two kinds of waste, molten fly ash and waste PVC, was attempted to remove heavy metals from the ash as metal chloride for recovery as metal resources and also to convert the residual ash into functional materials for environmental applications. For feasibility study, firstly, the characteristics of the residue after heating of the mixture of the ash and PVC were investigated, and secondly material conversions of raw ash and the residual ash were undertaken under identical conditions, using $\mathrm{NaOH}$ as the activation reagent, and the products were compared. As a result, a new treatment technology which enables advanced detoxification of molten fly ash and effective utilization of the residue was suggested.

\section{EXPERIMENTAL}

Molten fly ash, which was discharged from one of the melting furnace plants in Japan, was used in this study, and PVC powder was purchased from Wako Pure Industries, Ltd., Japan. Morphologies of these samples were shown in Figure 1. Experimental procedure is shown in Figure 2. The raw ash was
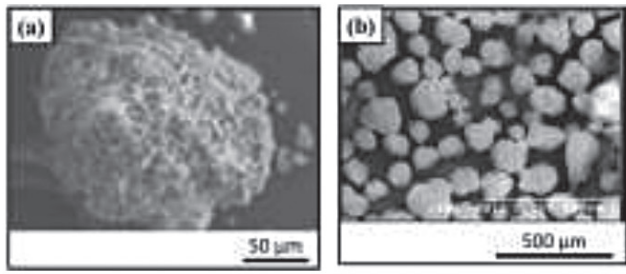

Figure 1 SEM photographs of (a) molten fly ash and (b) PVC.

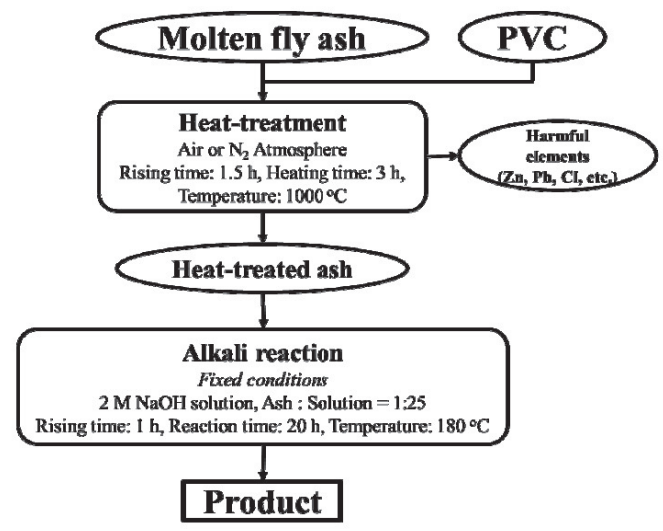

Figure 2 Flow chart of this experiments. heated at $1000^{\circ} \mathrm{C}$ in air and $\mathrm{N}_{2}$ atmosphere with or without PVC to separate harmful elements such as $\mathrm{Na}, \mathrm{K}, \mathrm{Cl}, \mathrm{Zn}$ and $\mathrm{Pb}$ from the ash. Then, the heat-treated ash was treated with alkali solution to convert into functional materials.

\subsection{Reduction of harmful contents}

Air-heating and $\mathrm{N}_{2}$-heating were attempted to apply for reduction of harmful content in molten fly ash.

Air-heating was performed as follows. Two g of molten fly ash was put in an alumina crucible, and set in an electric furnace. The furnace heated the crucible with increasing temperature to $1000^{\circ} \mathrm{C}$ for $2 \mathrm{~h}$, and then heated at $1000^{\circ} \mathrm{C}$ for $3 \mathrm{~h}$. After heating, the crucible was cooled to room temperature to obtain the ash treated with airheating.

$\mathrm{N}_{2}$-heating was performed in a horizontal reactor as follows. Two g of molten fly ash was put in a ceramic board, and installed in a transparent quartz tube of $0.45 \mathrm{~m}$ inside diameter and $1 \mathrm{~m}$ in length. Before heating, $\mathrm{N}_{2}$ gas was injected into the tube for $30 \mathrm{~min}$ at a rate of $1.0 \mathrm{~L} / \mathrm{min}$ to replace the air in the tube. The electric tube furnace heated the ash in the reactor with increasing temperature to $1000^{\circ} \mathrm{C}$ for $1.5 \mathrm{~h}$, and then the ash was heated at $1000^{\circ} \mathrm{C}$ for $3 \mathrm{~h}$, with a continuous flow of $\mathrm{N}_{2}$ gas at a rate of $1.0 \mathrm{~L} / \mathrm{min}$. After heating, the product was cooled to room temperature with a steady $\mathrm{N}_{2}$ gas flow $(1.0 \mathrm{~L} / \mathrm{min})$ in the tube to obtain the ash treated with $\mathrm{N}_{2}$-heating.

In this experiment, four heating treatment processes with different combinations of air-heating for removal of organic carbonaceous content, and $\mathrm{N}_{2}$-heating for reduction of metal oxides were carried out (Figure 3). While molten fly ash was used directly for heating in process- 1 and pocess-2, the mixture of the ash and PVC, which $1 \mathrm{~g}$ of the ash was mixed with $1 \mathrm{~g}$ of PVC in a mortar, was used in process- 3 and process- 4 . Process- 1 and process- 2 involved obtaining the ashes treated with air-heating (Ash-1) and $\mathrm{N}_{2}$-heating (Ash-2), respectively. Process-3 involved obtaining the ash with $\mathrm{N}_{2}$-heating from the mixture of molten fly ash and PVC (Ash-3), and process-4 involved obtaining the ash with air-heating from ash-3 (Ash-4). The mineralogical and chemical compositions of obtained ashes were analyzed, and reduction of harmful elements in the ash was determined by elution test.

\subsection{Elution test}

Elution tests were carried out on raw ash and treated ashes. $0.1 \mathrm{~g}$ of the ash was added to $10 \mathrm{~mL}$ of distilled water in $50 \mathrm{~mL}$ of tube, and then the tube was shaken for 12 hour with reciprocal shaker. After shaking at room temperature, the suspension was centrifuged to collect the supernatant. The concentrations of $\mathrm{Na}^{+} . \mathrm{K}^{+}, \mathrm{Cl}^{-}, \mathrm{Zn}^{2+}$,

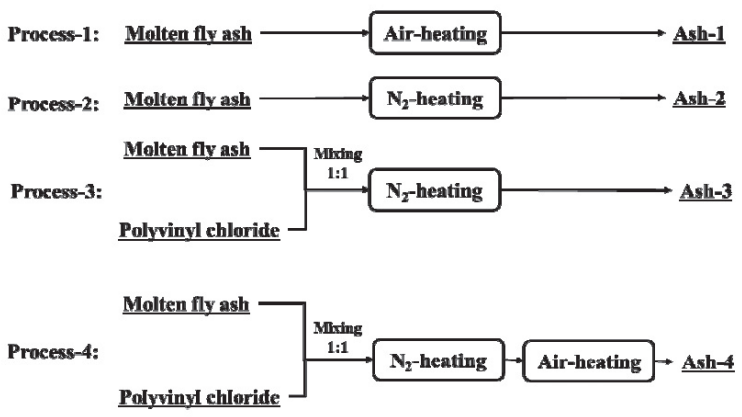

Figure 3 Flow chart of the four processes. 
Table 1 Chemical compositions of raw ash, the products from raw ash and Ash-4.

\begin{tabular}{|c|c|c|c|c|c|c|c|c|c|c|c|c|c|}
\hline & \multicolumn{13}{|c|}{ Chemical composition (wt. \%) } \\
\hline & $\mathrm{Na}_{2} \mathrm{O}$ & $\mathrm{K}_{2} \mathrm{O}$ & $\mathrm{Cl}$ & $\mathrm{ZnO}$ & $\mathrm{PbO}$ & $\mathrm{CuO}$ & $\mathrm{SiO}_{2}$ & $\mathrm{Al}_{2} \mathrm{O}_{3}$ & $\mathrm{CaO}$ & $\mathrm{MgO}$ & $\mathrm{Fe}_{2} \mathrm{O}_{3}$ & $\mathrm{P}_{2} \mathrm{O}_{5}$ & $\mathrm{SO}_{3}$ \\
\hline Raw ash & 14.9 & 8.6 & 11.0 & 11.7 & 1.8 & 0.6 & 11.9 & 9.0 & 16.0 & 1.9 & 1.4 & 5.6 & 5.4 \\
\hline Product from raw ash & N.D. & 1.0 & 0.4 & 8.5 & 1.2 & 0.9 & 23.4 & 11.1 & 35.0 & 4.6 & 2.4 & 10.4 & 1.3 \\
\hline Product from Ash-4 & N.D. & 0.6 & 0.7 & 1.9 & N.D. & 0.9 & 26.3 & 12.6 & 37.5 & 4.4 & 2.7 & 11.6 & 0.8 \\
\hline
\end{tabular}

N. D.: Not detected

$\mathrm{Pb}^{2+}$ and $\mathrm{Cu}^{2+}$ in the supernatant were measured, and the elution amounts of each elements from the ashes $\left(q_{M}\right)$ were calculated as follows;

$$
q M=C \cdot V / w \quad \mathrm{M}: \mathrm{Na}^{+}, \mathrm{K}^{+}, \mathrm{Cl}, \mathrm{Zn}^{2+}, \mathrm{Pb}^{2+}, \mathrm{Cu}^{2+}
$$

where $C$ is the concentration of each elements in the supernatant after elution test $(\mathrm{mg} / \mathrm{L}), V$ is the volume of aqueous solution (L), and $w$ the weight of the ash added to distilled water $(\mathrm{g})$.

\subsection{Material conversion}

Material conversion was performed in $50 \mathrm{~mL}$ Teflon-lined autoclave. $0.2 \mathrm{~g}$ of the ash was added into $5 \mathrm{~mL}$ of $2 \mathrm{M} \mathrm{NaOH}$ solution in autoclave, and then heated at $180^{\circ} \mathrm{C}$ for $20 \mathrm{~h}$ in electric furnace. After reaction, the solid product was separated from the solution by filtration, washed with distilled water and dried at $60^{\circ} \mathrm{C}$ overnight in a drying oven. The mineralogical phases of obtained products were determined.

\subsection{Analysis}

The mineralogical compositions of samples were determined by X-ray diffraction (Ultima, Rigaku, Japan), and chemical compositions of samples for typical main elements of incinerated fly ash as oxides, $\mathrm{Na}_{2} \mathrm{O}, \mathrm{K}_{2} \mathrm{O}, \mathrm{Cl}, \mathrm{ZnO}, \mathrm{PbO}, \mathrm{CuO}, \mathrm{SiO}_{2}, \mathrm{Al}_{2} \mathrm{O}_{3}$, $\mathrm{CaO}, \mathrm{MgO}, \mathrm{Fe}_{2} \mathrm{O}_{3}, \mathrm{P}_{2} \mathrm{O}_{5}$ and $\mathrm{SO}_{3}$, were analyzed by X-ray fluorescence (Primini, Rigaku, Japan). The morphologies of the samples were observed with scanning electron microscope (JSM890, JEOL, Japan). The concentrations of $\mathrm{Na}^{+}, \mathrm{K}^{+}, \mathrm{Zn}^{2+}, \mathrm{Pb}^{2+}$ and $\mathrm{Cu}^{2+}$ in the solution were analyzed by inductively-coupled plasma spectrometry (SPS4000, SEIKO, Japan), and $\mathrm{Cl}^{-}$concentration in the solution was measured by ion chromatograph (ICS-3000, Dionex, Japan).

\section{RESULTS AND DISCUSSION}

\subsection{Characterization of heat-treated ashes}

Table 1 and figure 4 show the chemical and mineralogical compositions of molten fly ash and heat-treated ashes, respectively. Molten fly ash contains high amount of sodium, potassium and chloride as $\mathrm{NaCl}$ and $\mathrm{KCl}$, and heavy metals, lead, zinc and copper, in the oxide forms $\mathrm{PbO}, \mathrm{ZnO}$, and $\mathrm{CuO}$. Therefore, in this research, we classified $\mathrm{Na}, \mathrm{K}, \mathrm{Cl}, \mathrm{Zn}, \mathrm{Pb}$ and $\mathrm{Cu}$ as the harmful substances for elution test, and others are residual elements in the ash to synthesize functional materials. For mineral phases of heat-treated ashes, gehlenite $\left(\mathrm{Ca}_{2} \mathrm{Al}_{2} \mathrm{SiO}_{7}\right)$ mainly contains, and $\mathrm{NaCl}$ and $\mathrm{KCl}$ became minor, due to the melting point of $\mathrm{NaCl}\left(318^{\circ} \mathrm{C}\right)$ and $\mathrm{KCl}$ $\left(776^{\circ} \mathrm{C}\right)$. The peaks of gehlenite is the highest and other peaks, which indicates harmful substances, are the lowest for Ash-4 via $\mathrm{N}_{2}$-heating and air-heating with PVC.

Table 2 shows the solubility of harmful elements from raw ash and heated ashes. The solubility of $\mathrm{Na}^{+}, \mathrm{K}^{+}$and $\mathrm{Cl}^{-}$in Ash-1 is lower than those in raw ash, and those in Ash-2, Ash-3 and Ash4 are far lower than those in raw ash. These results suggested that heat-treatment can reduce the elution of $\mathrm{Na}^{+}, \mathrm{K}^{+}$and $\mathrm{Cl}^{-}$from the ash, and the reduction of these elements elution using $\mathrm{N}_{2}$-heating

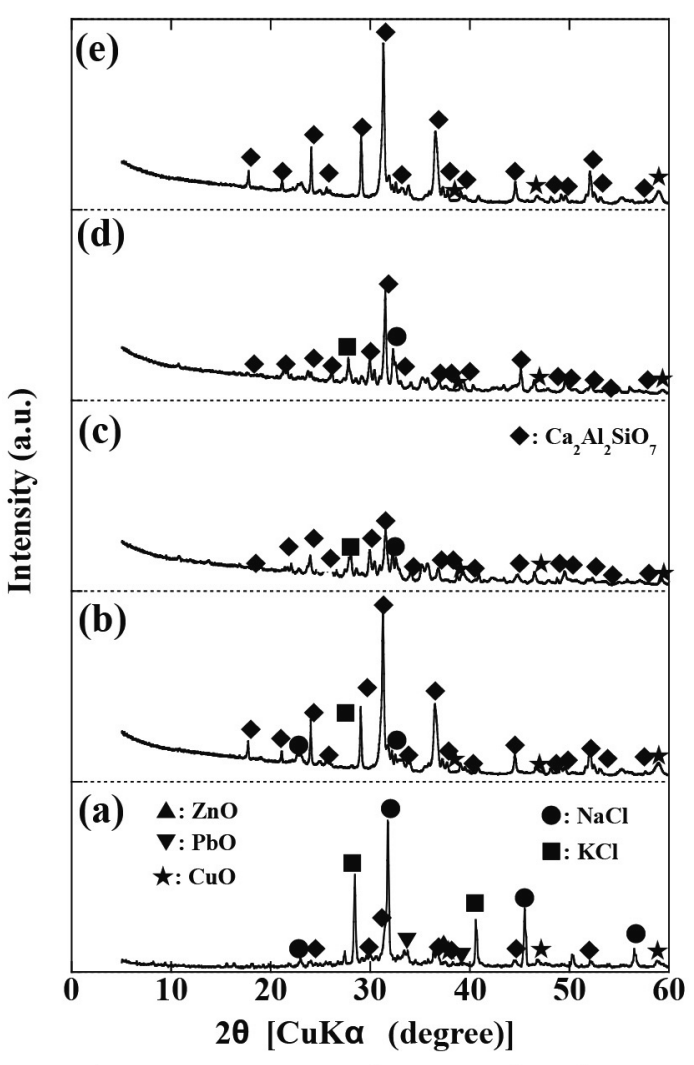

Figure 4 shows XRD patterns of (a) raw ash, Ash-1, (c) Ash-2, (d) Ash-3 and (e) Ash-4.

Table 2 Solubility of harmful elements from raw ash and heat-treated ashes.

\begin{tabular}{|c|c|c|c|c|c|c|}
\hline & \multicolumn{6}{|c|}{ Solubility $(\mathrm{mg} / \mathrm{g})$} \\
\cline { 2 - 7 } & $\mathrm{Na}^{+}$ & $\mathrm{K}^{+}$ & $\mathrm{Cr}$ & $\mathrm{Zn}^{2+}$ & $\mathrm{Pb}^{2+}$ & $\mathrm{Cu}^{2+}$ \\
\hline Molten fly ash & 54.0 & 62.7 & 210.7 & 0.26 & 0.24 & 0.17 \\
\hline Ash-1 & 32.3 & 13.0 & 146.5 & 0.21 & 0.33 & 0.17 \\
\hline Ash-2 & 27.6 & 11.3 & 17.9 & 0.31 & 0.27 & 0.17 \\
\hline Ash-3 & 0.6 & 0.6 & 43.9 & 0.13 & N.D. & 0.17 \\
\hline Ash-4 & N.D. & N.D. & 10.8 & N.D. & N.D. & 0.17 \\
\hline
\end{tabular}

N. D. : Not Detected

is higher than that using air-heating. In addition, the reduction of $\mathrm{Na}^{+}$and $\mathrm{K}^{+}$using $\mathrm{N}_{2}$-heating with PVC is higher than those without PVC. For heavy metals, the elution of $\mathrm{Zn}^{2+}$ and $\mathrm{Pb}^{2+}$ can be reduced by heat-treatment with PVC, while those are almost same by heattreatment without PVC. Regardless of heat-treatment, the elution of $\mathrm{Cu}^{2+}$ is unchanged, which is consistent with the $\mathrm{CuO}$ remain in the ash shown in Figure 4. In Ash-1 and Ash-2, $\mathrm{NaCl}$ and $\mathrm{KCl}$ were melted, but metal chlorides to be vaporized were not formed because metal oxides in the ash are difficult to react with chloride [12]. On the other hands, in Ash-3 and Ash-4, metal oxides were reduced by $\mathrm{PVC}$ via $\mathrm{N}_{2}$-heating, and sufficient amount of chloride from $\mathrm{NaCl}, \mathrm{KCl}$ and $\mathrm{PVC}$ was reacted with reduced metals to form 
Table 3 Chemical compositions for raw ash and heat-treated ashes

\begin{tabular}{|c|c|c|c|c|c|c|c|}
\hline & \multicolumn{7}{|c}{ Chemical composition (wt. \%) } \\
\cline { 2 - 9 } & $\mathrm{SiO}_{2}$ & $\mathrm{Al}_{2} \mathrm{O}_{3}$ & $\mathrm{CaO}$ & $\mathrm{MgO}$ & $\mathrm{Fe}_{2} \mathrm{O}_{3}$ & $\mathrm{P}_{2} \mathrm{O}_{5}$ & $\mathrm{SO}_{3}$ \\
\hline Molten fly ash & 23.2 & 17.6 & 31.2 & 3.8 & 2.8 & 10.9 & 10.5 \\
\hline Ash-1 & 22.8 & 16.6 & 33.0 & 4.2 & 2.6 & 10.5 & 10.3 \\
\hline Ash-2 & 24.2 & 16.7 & 32.8 & 3.9 & 2.7 & 10.7 & 9.0 \\
\hline Ash-3 & 21.3 & 17.2 & 35.1 & 3.4 & 3.0 & 12.6 & 7.4 \\
\hline Ash-4 & 24.8 & 17.4 & 34.5 & 4.6 & 2.5 & 11.1 & 5.1 \\
\hline
\end{tabular}

N. D. : Not Detected

metal chloride [8-10]. For Ash-4, residual carbon and chloride after $\mathrm{N}_{2}$-heating were reacted with residual metals via air-heating. In addition, oxides of zinc and lead can be removed easier than that of cupper in the ash by chlorination and carbo-chlorination, due to the difference of energy to form metal or metal chloride [12]. Therefore, removal of each metals in the ash are different, and $\mathrm{CuO}$ remained in the heat-treated ash on this experimental condition.

Table 3 shows the composition of residual elements in the ash. It is noted that the composition of each ash is calculated that 7 elements total is $100 \%$. Regardless of heat-treatments, the residual elements in heat-treated ashes are almost same as those ashes, which means that all ashes are almost same characteristics to synthesize functional materials. These results suggested that heattreatment is effective for the reduction of harmful substances elution, and Ash-4 via two-step heating is the best for elution inhibition and remaining the elements as raw material to synthesize functional materials. It is noted that weight reduction of the ash by treatment are $62.7 \%$ (Ash-1), 60.0\% (Ash-2), 36.4\% (Ash-3) and $26.2 \%$ (Ash-4), respectively, which means that waste reduction can be done by these treatment by burning carbonaceous contents and vaporizing metal oxide contents in the ash.

\subsection{Products from raw ash and treated ash}

Figure 5 and Table 1 show XRD patterns and chemical compositions of the products synthesized from (a) raw ash and (b) Ash-4, respectively. In the products from both ashes, tobermorite $11 \AA\left[\mathrm{Ca}_{5} \mathrm{Si}_{6} \mathrm{O} 1_{5}(\mathrm{OH})_{2} \cdot 5 \mathrm{H}_{2} \mathrm{O}\right]$ and hydroxyapatite $\left[\mathrm{Ca}_{10}\left(\mathrm{PO}_{4}\right)\right.$ $(\mathrm{OH})_{2}$ ] appeared, and both products hava almost same chemical compositions, except $\mathrm{ZnO}$ and $\mathrm{PbO}$. Tobermorite is the most

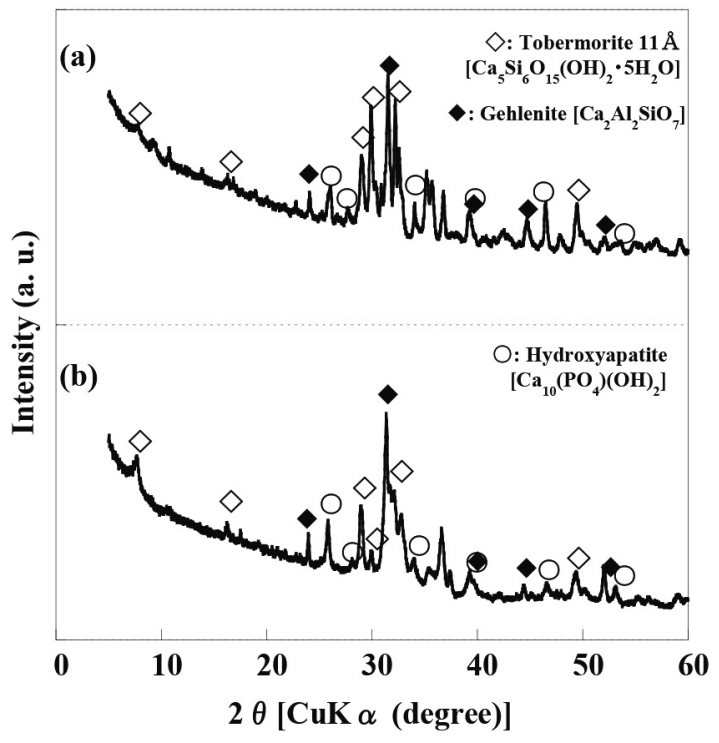

Figure 5 XRD patterns of the product from (a) raw ash and (b) Ash-4. important compound in various hydrous calcium silicates and can act as a cation exchanger for $\mathrm{NH}_{4}^{+}, \mathrm{Cs}^{+}, \mathrm{Sr}^{2+}$ and so on [23, 24]. Hydroxyapatite is inorganic ion exchanger for both cation, $\mathrm{Pb}^{2+}, \mathrm{Cd}^{2+}$, etc., and anion, F, etc. [25]. These are indicated that functional material with low harmful elements can be synthesized from the ash via heat-treatment.

\section{CONCLUSION}

A new two-step process, heating-treatment to separate harmful substances, such as $\mathrm{Na}, \mathrm{K}, \mathrm{Cl}, \mathrm{Zn}$ and $\mathrm{Pb}$, from the ash, and chemical conversion from the ash into functional materials with sodium hydroxide, was attempted. In heating-treatment, elution of $\mathrm{Na}^{+}, \mathrm{K}^{+}$and $\mathrm{Cl}^{-}$decrease using both air-heating and $\mathrm{N}_{2}$-heating, those of $\mathrm{Zn}^{2+}$ and $\mathrm{Pb}^{2+}$ can be reduced by $\mathrm{N}_{2}$-heating with PVC, but that of $\mathrm{Cu}^{2+}$ are unchanged by all heating-treatment. Mineral phases in heat-treated ash are mainly gehlenite, and the product from heattreated ash via alkali reaction with $2 \mathrm{M} \mathrm{NaOH}$ solution at $180^{\circ} \mathrm{C}$ for $20 \mathrm{~h}$ contains tobermorite $11 \AA$ and hydroxyapatite, and lower harmful substances, $\mathrm{ZnO}$ and $\mathrm{PbO}$, than raw ash. Further research to optimize the treatment conditions, assess the heavy metal recovery and effect an appraisal of the potential of the material in wastewater treatment application is warranted.

Acknowledgment - "This work was supported by the Sumitomo Foundation."

\section{References}

[1] Kojima, K., Kamiki, T., Shiokawa, S., Tsujimoto, T.; "Technology development for treatment of secondary fly ashes from municipal waste incineration - decontamination and metals recovery using the MF process", Shigen to Sozai, 121, 341-345 (2005) (in Japanese).

[2] Nagasaki, H.; "Reclaiming of heavy metals from molten fly ash as a raw material for smelting", J. Jpn. Waste Manage. Assoc., 51, 605-610 (1998) (in Japanese).

[3] Okada, T., Tojo, Y., Tanaka, N., Matsuto, T.; "Recovery of zinc and lead from fly ash from ash-melting and gasificationmelting processes of MSW - comparison and applicability of chemical leaching methods", Waste Manage., 27, 69-80 (2007).

[4] Nagib, S., Inoue, K.; "Recovery of lead and zinc from fly ash generated from municipal incineration plants by means of acid and/or alkaline leaching", Hydrometall., 56, 269-292 (2000).

[5] Katsuura, H., Inoue, T., Hiraoka, M., Sakai, S.; "Full-scale plant study on fly ash treatment by the acid-extraction process", Waste Manage., 16, 491-499 (1996).

[6] Ferreira, C., Jensen, P., Ottosen, L., Ribeiro, A.; "Removal of selected heavy metals from MSW fly ash by the electrodialytic process", Eng. Geol., 77, 339-347 (2005).

[7] Takaoka, M., Kawai, T., Takeda, N., Oshita, K.; "Recovery of heavy metals in fly ash from an ash melting furnace by solvent extraction”, Environ. Eng. Res., 39, 403-412 (2002).

[8] Nonaka, R., Sugawara, K., Sugawara, T.; "Release behavior of zinc and lead from molten fly ash", Kagaku Kogaku Ronbunshu, 30, 715-720 (2004) (in Japanese).

[9] Nonaka, R., Sugawara, K., Sugawara, T., Enda, Y.; "Chlorination behavior of zinc and lead from molten fly ashes: effects of metal forms and coexisting elements", Kagaku Kogaku Ronbunshu, 31, 278-284 (2005) (in Japanese).

[10] Nonaka, R., Yamaguchi, Y., Sugawara, K.; "Chemical form 
change and volatilization behavior of zinc during chlorination of molten fly ashes", Kagaku Kogaku Ronbunshu, 33, 495500 (2007) (in Japanese).

[11] Menad, N., Bjorkman, B.; "Polyvinyl chloride used as a chlorinating and a reducing agent", Resour. Conserv. Recycl., 24, 257-274 (1998).

[12] Nakayama, K., Dalibor, K., Sakai, K., Kubota, M., Matsuda, H.; "Effect of unburned carbon on lead, zinc, and copper recovery from molten fly ash by chloride-induced volatilization”, J. Mater. Cycles Waste Manage., 10, 102-109 (2008).

[13] Takeda, N., Okajima, N., Nagasawa, M., Mine, K.; "Fundamental study on separation of heavy metals from fly ash by chlorideinduced volatilization", Kankyo Eisei Kougaku kenkyu, 8, 185-190 (1994).

[14] Jakob, A., Stucki, S., Kuhn, P.; "Evaporation of heavy metals during the heat treatment of municipal solid waste incinerator fly ash”, Environ. Sci. Technol., 29, 2429-2436 (1995).

[15] Chan, C., Kirk, D.; "Behavior of metals under the conditions of roasting MSW incinerator fly ash with chlorinating agents", J. Hazard. Mater., B64, 75-89 (1999).

[16] Kudo, T.; "The utilization of industrial wastes at the Tobata plant of Kowa Seiko Co., Ltd.”, Shigen to Sozai, 109, 11241128 (1993) (in Japanese).

[17] Nakayama, K., Tajima, Y., Mizuno, S. Kojima, Y., Matusda, H., Takeda, M.; "Effect of $\mathrm{NaCl}, \mathrm{KCl}$ and $\mathrm{CaCl}_{2}$ contained in MSW molten fly ashes on chloride volatilization of heavy metal”, Kagaku Kogaku Ronbunshu, 30, 778-785 (2004).

[18] Siddique, R., Khatib, J., Kaur, I.; "Use of recycled plastic in concrete: A review”, Waste Manage., 28, 1835-1852 (2007).

[19] Querol, X., Moreno, N., Umaña, J. C., Alastuey, A., Hernández, E., López-Solar, A., Plana, F.; "Synthesis of zeolites from coal fly ash: an overview," Int. J. Coal Geol., 50, 413-423 (2002).

[20] Wajima, T., Ikegami, Y.; "Zeolite synthesis from paper sludge ash via acid leaching," Chem. Eng. Commun., 195, 305-315 (2008).

[21] Wajima, T., Ishimoto, H., Kuzawa, K., Ito, K., Tamada, O., Gunter, M. E., Racovan, J. F.; "Material conversion from paper sludge ash in $\mathrm{NaOH}, \mathrm{KOH}$, and $\mathrm{LiOH}$ solutions," Am. Mineral., 92, 1105-1111 (2007).

[22] Wajima, T., Shimizu, T., Ikegami, Y.; "Zeolite synthesis from paper sludge ash with addition of diatomite," J. Chem. Technol. Biotechnol., 83, 921-927 (2008).

[23] Yao, Z., Tamura, C. Matsuda, M., Miyake, M.; "Resource recovery of waste incineration fly ash: synthesis of tobermorite as ion exchanger," J. Mater. Res., 14, 4437-4442 (1999).

[24] Ma, W., Brown, P. W., Komarneni, S.; "Sequestration of cesium and strontium by tobermorite synthesized from fly ash", J. Am. Ceram. Soc., 79, 1707-1710 (1996).

[25] Inoue, K., Kuriyama, M., Ohto, K., Oshima, T., Furuta, S., Makino, K.; "Adsorption removal of fluoride by hydroxyapatite prepared from spent mold gypsum", Kagaku Kogaku Ronbunshu, 30, 206-210 (2004) (in Japanese). 